TITLE:

\title{
Expression of breast cancer resistance protein is associated with a poor clinical outcome in patients with small-cell lung cancer.
}

\section{AUTHOR(S):}

Kim, Young Hak; Ishii, Genichiro; Goto, Koichi; Ota, Shuji; Kubota, Kaoru; Murata, Yukinori; Mishima, Michiaki; Saijo, Nagahiro; Nishiwaki, Yutaka; Ochiai, Atsushi

\section{CITATION:}

Kim, Young Hak ... [et al]. Expression of breast cancer resistance protein is associated with a poor clinical outcome in patients with small-cell lung cancer.. Lung cancer 2009, 65(1): 105-111

\section{ISSUE DATE:}

2009-07

URL:

http://hdl.handle.net/2433/137383

\section{RIGHT:}

(c) 2008 Elsevier Ireland Ltd; This is not the published version. Please cite only the published version.; この論文は出版社版でありません。引 用の際には出版社版をご確認ご利用ください。 
Expression of Breast Cancer Resistance Protein is Associated with a Poor Clinical

Outcome in Patients with Small-Cell Lung Cancer.

Young Hak Kim, ${ }^{1,2,3}$ Genichiro Ishii, ${ }^{1}$ Koichi Goto,${ }^{2}$ Shuji Ota, ${ }^{1,2}$ Kaoru Kubota, ${ }^{2}$

Yukinori Murata, ${ }^{1}$ Michiaki Mishima, ${ }^{3}$ Nagahiro Saijo,${ }^{2}$ Yutaka Nishiwaki, ${ }^{2}$ and Atsushi Ochiai $^{1}$

${ }^{1}$ Pathology Division, Research Center for Innovative Oncology, National Cancer Center Hospital East, Chiba, Japan; ${ }^{2}$ Division of Thoracic Oncology, National Cancer Center Hospital East, Chiba, Japan; ${ }^{3}$ Department of Respiratory Medicine, Kyoto University Hospital, Kyoto, Japan

Correspondence: Atsushi Ochiai; E-mail: aochiai@east.ncc.go.jp; Address: Pathology

Division, Research Center for Innovative Oncology, National Cancer Center Hospital

East, 6-5-1 Kashiwanoha, Kashiwa, Chiba 277-8577, Japan; Phone:

+81-4-7134-6855; Fax: +81-4-7134-6865

Running Title: BCRP expression in SCLC

Keywords: SCLC, MDR, ABC transporter, DNA excision repair, BCRP 


\section{Summary}

Background: ATP-binding cassette (ABC) transporter and DNA excision repair proteins play a pivotal role in the mechanisms of drug resistance. The aim of this study was to investigate the expression of $\mathrm{ABC}$ transporter and DNA excision repair proteins, and to elucidate the clinical significance of their expression in biopsy specimens from patients with small-cell lung cancer (SCLC).

Methods: We investigated expression of the ABC transporter proteins, P-glycoprotein (Pgp), multidrug resistance associated-protein 1 (MRP1), MRP2, MRP3, and breast cancer resistance protein (BCRP), and the DNA excision repair proteins, excision repair cross-complementation group 1 (ERCC1) protein and breast cancer susceptibility gene 1 (BRCA1) protein, in tumor biopsy specimens obtained before chemotherapy from 130 SCLC patients who later received platinum-based combination chemotherapy, and investigated the relationship between their expression and both response and survival.

Results: No significant associations were found between expression of Pgp, MRP1, MRP2, MRP3, ERCC1, or BRCA1 and either response or survival. However, there was a significant association between BCRP expression and both response $(p=0.026)$ and progression-free survival (PFS; $p=0.0103)$.

Conclusions: BCRP expression was significantly predictive of both response and 
progression-free survival (PFS) in SCLC patients receiving chemotherapy. These findings suggest that BCRP may play a crucial role in drug resistance mechanisms, and that it may serve as an ideal molecular target for the treatment of SCLC. 


\section{INTRODUCTION}

Lung cancer is the leading cause of cancer-related deaths in many industrialized countries. Although the proportion of patients with small-cell lung cancer (SCLC) has been decreasing, it still accounts for approximately $15 \%$ of all cases of lung cancer. SCLC is one of the most chemo-sensitive solid tumors, but the vast majority of patients eventually experience a relapse, and as a result the median survival time is 14-20 months for limited disease (LD) and 7-10 months for extensive disease (ED)(1).

Intrinsic or acquired drug resistance is considered to be a major factor limiting the effectiveness of chemotherapy. Drug resistance by tumors occurs not only to a single cytotoxic agent, but in the form of cross-resistance to other cytotoxic agents, called multidrug resistance (MDR). One of the major mechanisms of MDR is increased ability of tumor cells to actively efflux drugs, which leads to a decrease in intracellular drug accumulation, and the mechanism is mediated by ATP-dependent drug efflux pumps that are known as ATP-binding cassette (ABC) transporters $(2,3)$. To date, at least 48 human $\mathrm{ABC}$ transporters have been identified, and they have been divided into seven subfamilies, ABC-A through ABC-G. Five of them, P-glycoprotein (Pgp), multidrug resistance associated-protein 1 (MRP1), MRP2, MRP3, and breast cancer resistance protein (BCRP), have been most intensively investigated, and in vitro 
studies have demonstrated associations between their expression and resistance to cytotoxic drugs commonly used in the treatment of SCLC, including etoposide, irinotecan, and topotecan(4).

Another important mechanism of drug resistance is increased repair of DNA damage mediated by the DNA excision repair gene. Resistance to platinum is associated with increased removal of platinum-DNA adducts, and DNA excision repair plays a pivotal role in this process(5). Nucleotide excision repair (NER) is a major mechanism for repairing platinum-DNA adducts, and it is now known that there are two pathways in NER: transcription-coupled NER (TC-NER) and global genomic NER (GG-NER)(5). Among NER proteins, excision repair cross-complementation group 1 (ERCC1) protein, which is involved in the GG-NER pathway, has been most intensively investigated. Expression of ERCC1 has recently been shown to be a significant negative predictive factor for survival of non-small cell lung cancer (NSCLC) patients receiving cisplatin-based adjuvant chemotherapy(6). On the other hand, the results of an in vitro study have suggested the superiority of TC-NER pathway, in which breast cancer susceptibility gene 1 (BRCA1) protein is involved, to GG-NER pathway in predicting platinum resistance(7). Since platinum agents are considered to be key drugs in the treatment of SCLC as well as NSCLC(8-10), it is of great interest to 
determine whether there is an association between the expression of DNA excision repair genes and the effectiveness of platinum-based chemotherapy in SCLC patients.

In this retrospective study we investigated the immunohistochemical expression of the ABC transporter proteins, Pgp, MRP1, MRP2, MRP3, and BCRP, and the DNA excision repair proteins, ERCC1 protein and BRCA1 protein, in tumor biopsy specimens obtained before chemotherapy from 130 SCLC patients who later received platinum-based combination chemotherapy, and we investigated the relationship between their expression and the patients' clinical outcome. 


\section{MATERIALS AND METHODS}

\subsection{Subjects}

A total of 626 patients were diagnosed with SCLC at the National Cancer Center Hospital East between July 1992 and December 2005, and 578 of them received platinum-based combination chemotherapy as an initial treatment. After excluding the 246 patients who received thoracic radiotherapy and 2 patients who received surgery in order to eliminate the effects of treatment other than chemotherapy, the 191 patients of the remaining 330 patients diagnosed only cytologically, and therefore with no specimens available for analysis, and the nine patients whose specimens were unsuitable for immunohistochemistry. In this study, we analyzed biopsy specimens from 130 patients consisting of 104 responders and 26 non-responders. Institutional Review Board-approved informed consent was obtained from all patients.

\subsection{Clinical evaluation}

The classification system proposed by the Veterans' Administration Lung Study Group was used to stage SCLC as limited disease (LD) or extensive disease (ED)(11). LD is defined as disease confined to one hemithorax that can be encompassed within a single radiation field, and ED is defined as disease that extends beyond these confines. 
Performance status (PS) was determined based on the Eastern Cooperative Oncology

Group (ECOG) scale. Patient response was evaluated by using the Response Evaluation Criteria in Solid Tumors (RECIST)(12).

\subsection{Immunohistochemistry}

Tissue blocks were cut into $4-\mu \mathrm{m}$ sections and mounted on silane-coated slides (Matsunami, Tokyo, Japan). The slides were then deparaffinized in xylene and dehydrated in a graded alcohol series. For antigen retrieval, the slides for Pgp, MRP1, MRP2, BCRP, ERCC1, and BRCA1 were immersed in $10 \mathrm{mM}$ citric buffer solution (pH 6.0) at $120^{\circ} \mathrm{C}$ for $20 \mathrm{~min}$ and the slides for MRP3 were immersed in $1 \mathrm{mM}$ EDTA retrieval fluid $\left(\mathrm{pH} \mathrm{8.0)}\right.$ at $95^{\circ} \mathrm{C}$ for $20 \mathrm{~min}$. The slides were then allowed to cool for 1 $\mathrm{h}$ at room temperature and washed in PBS. Nonspecific binding was blocked by incubation with $2 \% \mathrm{BSA}$ plus $0.1 \% \mathrm{NaN}_{3}$ for $30 \mathrm{~min}$, and after draining off the blocking solution, the slides were incubated overnight at $4{ }^{\circ} \mathrm{C}$ with the primary antibodies listed in Table 1. Endogenous peroxidase was then blocked with $0.3 \% \mathrm{H}_{2} \mathrm{O}_{2}$ in methanol for 10 min, and after washing three times in PBS, the slides were incubated for 60 min with a labeled polymer En Vision+, peroxidase Mouse (DAKO, Glostrup, Denmark). The chromogen used was $2 \%$ 3,3'-diaminobenzidine in $50 \mathrm{mM}$ Tris buffer $(\mathrm{pH}$ 7.6) 
containing $0.3 \%$ hydrogen, and the slides were counterstained with hematoxylin.

Normal human liver tissue was used as a positive control for Pgp, MRP2, MRP3, and BCRP, normal human lung tissue for MRP1, normal human tonsil tissue for ERCC1, and breast cancer tissue human for BRCA1. Negative controls for each antibody were prepared by using non-immune serum instead of the primary antibodies. Membranous or cytoplasmic staining was evaluated for ABC transporter proteins(13), while nuclear staining was evaluated for DNA excision repair proteins $(6,14)$. Staining of each antibody was considered positive if $>10 \%$ of the tumor cells stained. All of the slides were examined and scored independently by two observers (Y. K. and G. I.) without knowledge of the patients' clinical data. When judgments differed between two observers, they discussed it until an agreement was reached.

\subsection{Statistical analysis}

The significance of the relationship between immunohistochemical expression and clinical variables or response to chemotherapy was evaluated by using the $\chi^{2}$ test or Fisher's exact test, as appropriate. The logistic regression model was used for multivariate analysis of response. Progression-free survival (PFS) was used as a clinical marker for duration of response to chemotherapy. Overall survival (OS) was 
measured from the start of chemotherapy to the date of death from any cause or the date patients were last known to be alive. Survival rates were calculated by the Kaplan-Meier method, and the statistical significance of any differences in PFS and OS were evaluated by a log-rank test. The Cox proportional hazards model was used for multivariate analysis of survival. $P$ values less than 0.05 were considered significant. All statistical analyses were performed using the statistical program StatView, Version 5.0 (Abacus Concepts, Berkley, CA). 


\section{RESULTS}

\subsection{Patient characteristics}

The patient characteristics are summarized in Table 2. The median age of the patients was 67 years (range, 28-83 years). More than $80 \%$ of the patients were male, and more than $80 \%$ had ED. Despite excluding patients who had received thoracic radiotherapy or surgery, our study included $18 \mathrm{LD}$ patients. The major reasons for omitting thoracic radiotherapy in these LD patients were the presence of a malignant pleural effusion (9 patients) and interstitial pneumonia (5 patients). PS was generally good; approximately $70 \%$ of the patients were PS 0 or 1 . All patients received chemotherapy containing etoposide, irinotecan, or topotecan. The details of administered chemotherapy are shown in Table 3.

\subsection{Expression of $A B C$ transporter and DNA excision repair proteins in SCLC}

The immunostaining of $\mathrm{ABC}$ transporter proteins was both membranous and cytoplasmic, whereas the immunostaining of the DNA excision repair proteins was mostly restricted to the nucleus. Forty-two (33\%) of the 130 tumors were Pgp-positive, 29 (22\%) were MRP1-positive, 25 (19\%) were MRP2-positive, 9 (7\%) were MRP3-positive, 48 (37\%) were BCRP-positive, 36 (27\%) were ERCC1-positive, and 
$109(83 \%)$ were BRCA1-positive. The relationships between expression of the ABC transporter and DNA excision repair proteins and the clinical variables are shown in

Table 4. BCRP expression was significantly greater in the PS 2-4 cases than in the PS $0-1$ cases $(p=0.0223)$. There were no significant correlations between expression of Pgp, MRP1, MRP2, MRP3, ERCC1, or BRCA1 and the clinical variables.

\subsection{Association between expression of $\mathrm{ABC}$ transporter and DNA excision repair proteins and clinical outcome}

The relationships between clinical variables and response to chemotherapy and survival are shown in Table 5. Response rate was not associated with any clinical variables, but PFS $(p=0.0199)$ and OS $(p=0.0159)$ were significantly associated with PS. Table 6 shows the associations between expression of $\mathrm{ABC}$ transporter and DNA excision repair proteins and response to chemotherapy and survival. BCRP expression was significantly predictive of response to chemotherapy ( $p=0.026)$, and MRP2 expression was marginally predictive $(p=0.0515)$.

The median follow-up time was 8.3 years, and 119 patients had been dead until the time of analysis. The results for survival showed that BCRP expression was significantly associated with PFS $(p=0.0103)$, but not with OS $(p=0.1427)$. No 
significant associations were observed between expression of Pgp, MRP1, MRP3, ERCC1, or BRCA1 and either response to chemotherapy or survival. Representative immunohistochemical staining of BCRP and MRP2 is shown in Fig. 1.

\subsection{Multivariate analysis for response and survival}

A multivariate analysis revealed that BCRP expression was significantly predictive of response to chemotherapy (Table 7). PFS was significantly associated with both PS ( $p$ $=0.0299)$ and BCRP expression $(p=0.0138)$, whereas OS was significantly associated with PS alone ( $p=0.0295$; Table 8$)$. The PFS and OS curves according to BCRP expression are shown in Fig. 2. 


\section{DISCUSSION}

Although initial chemotherapy succeeds in $80 \%$ to $90 \%$ of SCLC patients, most patients eventually experience a relapse and their survival time is quite limited. Unfortunately, little progress in the chemotherapy of SCLC has been made during the past 30 years(15). If drug resistance could be overcome, it would no doubt lead to an improved prognosis of this challenging disease, because drug resistance is considered a major obstacle to successful treatment. In this study we investigated expression of the five $A B C$ transporter proteins that are thought to be the most important in the drug resistance mechanisms of SCLC, and the results showed that BCRP expression alone was significantly associated with either response to chemotherapy or PFS. Expression of BCRP was significantly correlated with impaired PS, but the multivariate analysis revealed BCRP to be an independent prognostic factor for PFS.

BCRP, which is classified as ABCG2 and known as the mitoxantrone resistance gene $(\mathrm{MXR})$ or $\mathrm{ABC}$ transporter in placenta $(\mathrm{ABC}-\mathrm{P})$, is expressed in a variety of normal tissues, with the highest levels having been found in the placenta, and lower levels in the liver, small intestine, brain, and ducts and lobules of the breast $(2,16)$. BCRP was initially isolated from doxorubicin-resistant breast cancer cell line MCF-7, and its overexpression was found to promote resistance to topoisomerase I inhibitors, 
including irinotecan and topotecan(17). We previously reported the finding that BCRP expression is a significant predictor of survival in advanced NSCLC(18), but to our knowledge no data have been reported regarding BCRP expression in SCLC.

No significant association was found between the expression of other $\mathrm{ABC}$ transporter proteins and clinical outcome in the present study. Some studies have shown a relationship between expression of Pgp or MRP1 and response or survival(19-23), however, their clinical usefulness as therapeutic targets is still obscure. In fact, two randomized phase III studies that incorporated modulators of Pgp and one phase II study of VX-710, an inhibitor of both Pgp and MRP1, failed to show any survival benefit in SCLC patients(24-26).

In this study we also investigated the expression of the DNA excision repair proteins ERCC1 and BRCA1 in SCLC, but neither of them was related to response or survival. Expression of DNA excision repair proteins has hardly ever been investigated in SCLC, and to our knowledge there has been only one study in regard to it. In that study high expression of ERCC1 was associated with poor survival, but when the cases were grouped according to stage, a significant decrease in survival was observed only in the LD patients, and the correlation between ERCC1 expression and response was not mentioned(27). By contrast, expression of DNA excision repair 
proteins, especially ERCC1, has been intensively investigated in NSCLC recently, and expression of ERCC1 has been demonstrated to be related to platinum resistance in several studies $(6,28,29)$. We analyzed the ERCC1 expression also using the criterion by Olaussen et al. (6), but the results were similar and our conclusions did not change (data not shown). BRCA1 expression was also demonstrated to be significantly associated with chemoresistance in one study(30). However, in other studies no significant association was observed between expression of ERCC1 or BRCA1 and either response or survival $(14,31)$. Their clinical significance in lung cancer including SCLC has yet to be determined, and further studies are awaited.

The concept of "cancer stem cells", a very small fraction of the whole cell population repeating self-renewal continues to supply cancer-constitute cells, has recently gained wide acceptance. Although the origin of cancer stem cells has not yet been elucidated, the idea that malignant transformation of a normal stem cell has been proposed(32). Side population (SP) cells, defined by Hoechst 33342 dye exclusion in flow cytometry, are considered to be an enriched source of normal stem cells(33). In addition, BCRP has been shown to be a molecular determinant of the SP phenotype, and it can be used as a marker for stem cell selection(34). In a recent study, SP cells isolated from lung cancer displayed elevated expression of BCRP and showed resistance 
to multiple chemotherapeutic agents(35). These findings indicate that it may be possible to use BCRP as a marker of cancer stem cells in certain types of lung cancer.

In conclusion, the results of the present study indicated that immunohistochemical expression of BCRP is significantly associated with response and PFS in SCLC patients treated with platinum-based chemotherapy. Our results should be tested in LD patients who received thoracic radiotherapy, and it is also desirable that our results will be validated in other methods, such as mRNA expression analysis. Although confirmatory studies are needed, BCRP may be an ideal therapeutic target for SCLC. A variety of BCRP inhibitors have already been identified(36-39). Clinical trials of combination of these agents with conventional chemotherapy might be acceptable in SCLC. 


\section{Conflict of interest statement}

None declared.

\section{Acknowledgements}

This study was supported in part by a Grant-in-Aid for Third Term Comprehensive

10-year Strategy for Cancer Control from the Ministry of Health and Welfare of Japan. 


\section{REFERENCES}

1. Thatcher, N, Faivre-Finn, C, and Lorigan, P Management of small-cell lung cancer. Ann Oncol 2005; 16 Suppl 2: ii235-9.

2. Leonard, GD, Fojo, T, and Bates, SE The role of ABC transporters in clinical practice. Oncologist 2003; 8(5): 411-24.

3. Ozben, T Mechanisms and strategies to overcome multiple drug resistance in cancer. FEBS Lett 2006; 580(12): 2903-9.

4. Szakacs, G, Paterson, JK, Ludwig, JA, Booth-Genthe, C, and Gottesman, MM Targeting multidrug resistance in cancer. Nat Rev Drug Discov 2006; 5(3): 219-34.

5. Rosell, R, Cobo, M, Isla, D, et al. Applications of genomics in NSCLC. Lung Cancer 2005; 50 Suppl 2: S33-40.

6. Olaussen, KA, Dunant, A, Fouret, P, et al. DNA repair by ERCC1 in non-small-cell lung cancer and cisplatin-based adjuvant chemotherapy. N Engl J Med 2006; 355(10): 983-91.

7. Furuta, T, Ueda, T, Aune, G, Sarasin, A, Kraemer, KH, and Pommier, Y Transcription-coupled nucleotide excision repair as a determinant of cisplatin sensitivity of human cells. Cancer Res 2002; 62(17): 4899-902.

8. Pujol, JL, Carestia, L, and Daures, JP Is there a case for cisplatin in the treatment of small-cell lung cancer? A meta-analysis of randomized trials of a cisplatin-containing regimen versus a regimen without this alkylating agent. $\mathrm{Br} \mathrm{J}$ Cancer 2000; 83(1): 8-15.

9. Noda, K, Nishiwaki, Y, Kawahara, M, et al. Irinotecan plus cisplatin compared with etoposide plus cisplatin for extensive small-cell lung cancer. N Engl J Med 2002; 346(2): 85-91.

10. Hanna, N, Bunn, PA, Jr., Langer, C, et al. Randomized phase III trial comparing irinotecan/cisplatin with etoposide/cisplatin in patients with previously untreated extensive-stage disease small-cell lung cancer. J Clin Oncol 2006; 24(13): 2038-43.

11. Zelen, M Keynote address on biostatistics and data retrieval. Cancer Chemother Rep 3 1973; 4(2): 31-42.

12. Therasse, $\mathrm{P}$, Arbuck, SG, Eisenhauer, EA, et al. New guidelines to evaluate the response to treatment in solid tumors. European Organization for Research and Treatment of Cancer, National Cancer Institute of the United States, National Cancer Institute of Canada. J Natl Cancer Inst 2000; 92(3): 205-16.

13. Filipits, M, Haddad, V, Schmid, K, et al. Multidrug resistance proteins do not 
predict benefit of adjuvant chemotherapy in patients with completely resected non-small cell lung cancer: International Adjuvant Lung Cancer Trial Biologic Program. Clin Cancer Res 2007; 13(13): 3892-8.

14. Wachters, FM, Wong, LS, Timens, W, Kampinga, HH, and Groen, HJ ERCC1, $\mathrm{hRad} 51$, and BRCA1 protein expression in relation to tumour response and survival of stage III/IV NSCLC patients treated with chemotherapy. Lung Cancer 2005; 50(2): 211-9.

15. Spiro, SG and Silvestri, GA One hundred years of lung cancer. Am J Respir Crit Care Med 2005; 172(5): 523-9.

16. Haimeur, A, Conseil, G, Deeley, RG, and Cole, SP The MRP-related and BCRP/ABCG2 multidrug resistance proteins: biology, substrate specificity and regulation. Curr Drug Metab 2004; 5(1): 21-53.

17. Allen, JD and Schinkel, AH Multidrug resistance and pharmacological protection mediated by the breast cancer resistance protein (BCRP/ABCG2). Mol Cancer Ther 2002; 1(6): 427-34.

18. Yoh, K, Ishii, G, Yokose, T, et al. Breast cancer resistance protein impacts clinical outcome in platinum-based chemotherapy for advanced non-small cell lung cancer. Clin Cancer Res 2004; 10(5): 1691-7.

19. Savaraj, N, Wu, CJ, Xu, R, et al. Multidrug-resistant gene expression in small-cell lung cancer. Am J Clin Oncol 1997; 20(4): 398-403.

20. Kawasaki, M, Nakanishi, Y, Kuwano, K, Takayama, K, Kiyohara, C, and Hara, $\mathrm{N}$ Immunohistochemically detected $\mathrm{p} 53$ and P-glycoprotein predict the response to chemotherapy in lung cancer. Eur J Cancer 1998; 34(9): 1352-7.

21. Hsia, TC, Lin, CC, Wang, JJ, Ho, ST, and Kao, A Relationship between chemotherapy response of small cell lung cancer and P-glycoprotein or multidrug resistance-related protein expression. Lung 2002; 180(3): 173-9.

22. Yeh, JJ, Hsu, NY, Hsu, WH, Tsai, CH, Lin, CC, and Liang, JA Comparison of chemotherapy response with P-glycoprotein, multidrug resistance-related protein-1, and lung resistance-related protein expression in untreated small cell lung cancer. Lung 2005; 183(3): 177-83.

23. Triller, N, Korosec, P, Kern, I, Kosnik, M, and Debeljak, A Multidrug resistance in small cell lung cancer: expression of P-glycoprotein, multidrug resistance protein 1 and lung resistance protein in chemo-naive patients and in relapsed disease. Lung Cancer 2006; 54(2): 235-40.

24. Milroy, R A randomised clinical study of verapamil in addition to combination chemotherapy in small cell lung cancer. West of Scotland Lung Cancer Research 
Group, and the Aberdeen Oncology Group. Br J Cancer 1993; 68(4): 813-8.

25. Wood, L, Palmer, M, Hewitt, J, et al. Results of a phase III, double-blind, placebo-controlled trial of megestrol acetate modulation of

P-glycoprotein-mediated drug resistance in the first-line management of small-cell lung carcinoma. Br J Cancer 1998; 77(4): 627-31.

26. Gandhi, L, Harding, MW, Neubauer, M, et al. A phase II study of the safety and efficacy of the multidrug resistance inhibitor VX-710 combined with doxorubicin and vincristine in patients with recurrent small cell lung cancer. Cancer 2007; 109(5): 924-32.

27. Lee, HW, Han, JH, Kim, JH, et al. Expression of excision repair cross-complementation group 1 protein predicts poor outcome in patients with small cell lung cancer. Lung Cancer 2008; 59(1): 95-104.

28. Lord, RV, Brabender, J, Gandara, D, et al. Low ERCC1 expression correlates with prolonged survival after cisplatin plus gemcitabine chemotherapy in non-small cell lung cancer. Clin Cancer Res 2002; 8(7): 2286-91.

29. Takenaka, T, Yoshino, I, Kouso, H, et al. Combined evaluation of Rad51 and ERCC1 expressions for sensitivity to platinum agents in non-small cell lung cancer. Int J Cancer 2007; 121(4): 895-900.

30. Taron, M, Rosell, R, Felip, E, et al. BRCA1 mRNA expression levels as an indicator of chemoresistance in lung cancer. Hum Mol Genet 2004; 13(20): 2443-9.

31. Booton, R, Ward, T, Ashcroft, L, Morris, J, Heighway, J, and Thatcher, N ERCC1 mRNA expression is not associated with response and survival after platinum-based chemotherapy regimens in advanced non-small cell lung cancer. J Thorac Oncol 2007; 2(10): 902-6.

32. Dean, M, Fojo, T, and Bates, S Tumour stem cells and drug resistance. Nat Rev Cancer 2005; 5(4): 275-84.

33. Hadnagy, A, Gaboury, L, Beaulieu, R, and Balicki, D SP analysis may be used to identify cancer stem cell populations. Exp Cell Res 2006; 312(19): 3701-10.

34. Mao, Q and Unadkat, JD Role of the breast cancer resistance protein (ABCG2) in drug transport. Aaps J 2005; 7(1): E118-33.

35. Ho, MM, Ng, AV, Lam, S, and Hung, JY Side population in human lung cancer cell lines and tumors is enriched with stem-like cancer cells. Cancer Res 2007; 67(10): 4827-33.

36. Rabindran, SK, Ross, DD, Doyle, LA, Yang, W, and Greenberger, LM Fumitremorgin $\mathrm{C}$ reverses multidrug resistance in cells transfected with the 
breast cancer resistance protein. Cancer Res 2000; 60(1): 47-50.

37. Robey, RW, Steadman, K, Polgar, O, et al. Pheophorbide a is a specific probe for ABCG2 function and inhibition. Cancer Res 2004; 64(4): 1242-6.

38. Minderman, H, O'Loughlin, KL, Pendyala, L, and Baer, MR VX-710 (biricodar) increases drug retention and enhances chemosensitivity in resistant cells overexpressing P-glycoprotein, multidrug resistance protein, and breast cancer resistance protein. Clin Cancer Res 2004; 10(5): 1826-34.

39. Qadir, M, O'Loughlin, KL, Fricke, SM, et al. Cyclosporin A is a broad-spectrum multidrug resistance modulator. Clin Cancer Res 2005; 11(6): 2320-6. 


\section{FIGURE LEGENDS}

Fig. 1

Representative cases of positive immunostaining for BCRP $(\mathrm{A}, \times 100 ; \mathrm{B}, \times 400)$ and MRP2 $(C, \times 100 ; D, \times 400)$. BCRP and MRP2 in the apical membrane of the bronchial layer have been immunostained as a positive control.

Fig. 2

Progression-free survival curves (A) and overall survival curves (B) for 130 SCLC patients, according to breast cancer resistance protein (BCRP) expression. 
Table 1 Panel of primary antibodies

\begin{tabular}{cccccc}
\hline Antibody & Clone & Pretreatment & Dilution & City/nation & Source \\
\hline Pgp (mono) & JSB-1 & Autoclave & $1: 20$ & Newcastle/United Kingdom & Novocastra \\
MRP1 (mono) & MRPm6 & Autoclave & $1: 50$ & Uden/Netherlands & Sanbio \\
MRP2 (mono) & M2III-6 & Autoclave & $\mathbf{1 : 2 0}$ & Uden/Netherlands & Sanbio \\
MRP3 (mono) & DTX1 & Autoclave & $\mathbf{1 : 1 0 0}$ & Newcastle/United Kingdom & Novocastra \\
BCRP (mono) & BXP21 & Autoclave & $1: 20$ & Uden/Netherlands & Sanbio \\
ERCC1 (mono) & 8F1 & Autoclave & $\mathbf{1 : 1 0 0}$ & Warm Springs/United States & Lab vision \\
BRCA1 (mono) & MS110 & Microwave & $\mathbf{1 : 1 0 0}$ & San Diego/United States & Carbiochem \\
\hline
\end{tabular}


Table 2 Patient characteristics $(n=130)$

\begin{tabular}{lc}
\hline Characteristics & No. of patients $(\%)$ \\
\hline Age & 67 \\
Median & $28-83$ \\
Range & \\
Gender & $108(83)$ \\
Male & $22(17)$ \\
Female & \\
Disease extent & $18(14)$ \\
LD & $112(86)$ \\
ED & \\
Performance status & $2(2)$ \\
O & $93(71)$ \\
1 & $25(19)$ \\
2 & $8(6)$ \\
3 & $2(2)$ \\
4 & \\
Chemotherapy regimen & $36(28)$ \\
CE & $35(27)$ \\
PE & $25(19)$ \\
PI & $18(14)$ \\
CODE & $7(5)$ \\
CAV / PE & $7(5)$ \\
PEI & $2(2)$ \\
PT &
\end{tabular}

LD, limited disease ; ED, extensive disease;

CE, Carboplatin+Etoposide; PE, Cisplatin+Etoposide;

PI, Cisplatin+Irinotecan; CODE, Cisplatin+Vincristine +Doxorubicin+Etoposide; CAV/PE, Cyclophosphamide + Doxorubicin+Vincristine/Cisplatin+Etoposide; PEI,

Cisplatin+Etoposide+Irinotecan ; PT, Cisplatin+Topotecan 
Table 3 Details of administered chemotherapy

\begin{tabular}{|c|c|c|c|c|c|}
\hline regimen & \multicolumn{2}{|c|}{ dosage of each agent } & \multicolumn{2}{|l|}{ schedule } & median number of \\
\hline \multirow[t]{2}{*}{$\mathbf{C E}$} & Carboplatin & AUC 6 & day 1 & $q 3 w$ & \multirow{2}{*}{$4(1-4)$} \\
\hline & Etoposide & $100 \mathrm{mg} / \mathrm{m}^{2}$ & day 1-3 & & \\
\hline \multirow[t]{2}{*}{$\mathbf{P E}$} & Cisplatin & $60 \mathrm{mg} / \mathrm{m}^{2}$ & day 1 & q3w & \multirow{2}{*}{$4(1-4)$} \\
\hline & Etoposide & $100 \mathrm{mg} / \mathrm{m}^{2}$ & day 1-3 & & \\
\hline \multirow[t]{2}{*}{ PI } & Cisplatin & $60 \mathrm{mg} / \mathrm{m}^{2}$ & day 1 & $q 4 w$ & \multirow{2}{*}{$4(1-4)$} \\
\hline & Irinotecan & $60 \mathrm{mg} / \mathrm{m}^{2}$ & day $1,8,15$ & & \\
\hline \multirow[t]{4}{*}{ CODE } & Cisplatin & $25 \mathrm{mg} / \mathrm{m}^{2}$ & day $1(1,2,3,4,5,6,7,8,9$ week $)$ & weekly & \multirow{4}{*}{$9(2-9)$} \\
\hline & Vincristine & $1 \mathrm{mg} / \mathrm{m}^{2}$ & day $1(2,4,6,8$ week $)$ & & \\
\hline & Doxorubicin & $40 \mathrm{mg} / \mathrm{m}^{2}$ & day $1(1,3,5,7$ week $)$ & & \\
\hline & Etoposide & $80 \mathrm{mg} / \mathrm{m}^{2}$ & day $1-3(1,3,5,7$ week $)$ & & \\
\hline \multirow[t]{5}{*}{ CAV / PE } & Cyclophosphamide & $800 \mathrm{mg} / \mathrm{m}^{2}$ & day 1 & Iternatively & \multirow{5}{*}{$6(3-6)$} \\
\hline & Doxorubicin & $50 \mathrm{mg} / \mathrm{m}^{2}$ & day 1 & & \\
\hline & Vincristine & $1.4 \mathrm{mg} / \mathrm{m}^{2}$ & day 1 & & \\
\hline & Cisplatin & $80 \mathrm{mg} / \mathrm{m}^{2}$ & day 1 & & \\
\hline & Etoposide & $100 \mathrm{mg} / \mathrm{m}^{2}$ & day $1,3,5$ & & \\
\hline \multirow[t]{3}{*}{ PEI } & Cisplatin & $25 \mathrm{mg} / \mathrm{m}^{2}$ & day $1(1,2,3,4,5,6,7,8,9$ week $)$ & weekly & \multirow{3}{*}{$4(2-9)$} \\
\hline & Etoposide & $60 \mathrm{mg} / \mathrm{m}^{2}$ & day $1-3(1,3,5,7$ week $)$ & & \\
\hline & Irinotecan & $90 \mathrm{mg} / \mathrm{m}^{2}$ & day $1(2,4,6,8$ week $)$ & & \\
\hline \multirow[t]{2}{*}{ PT } & Cisplatin & $60 \mathrm{mg} / \mathrm{m}^{2}$ & day 5 & $q 3 w$ & \multirow{2}{*}{$4.5(4-5)$} \\
\hline & Topotecan & $1 \mathrm{mg} / \mathrm{m}^{2}$ & day 1-5 & & \\
\hline
\end{tabular}

AUC, area under the curve 
Table 4 Relationshin hetween clinical variables and exnression of ABC transnorter and DNA excision renair nroteins

\begin{tabular}{|c|c|c|c|c|c|c|c|c|}
\hline & n & Pgp-positive (\%) & MRP1-positive (\%) & MRP2-positive (\%) & MRP3-positive (\%) & BCRP-positive (\%) & ERCC1-positive (\%) & BRCA1-positive (\%) \\
\hline Total & 130 & $42(33)$ & $29(22)$ & $25(19)$ & $9(7)$ & $48(37)$ & $36(27)$ & $109(83)$ \\
\hline \multicolumn{9}{|l|}{ Age } \\
\hline$<70$ & 83 & $29(35)$ & $16(19)$ & $15(18)$ & $5(6)$ & $29(35)$ & $24(29)$ & $70(84)$ \\
\hline$\geq 70$ & 47 & $13(28)$ & $13(28)$ & $10(21)$ & $4(9)$ & $19(40)$ & $12(26)$ & $39(83)$ \\
\hline \multicolumn{9}{|l|}{ Gender } \\
\hline Male & 108 & 36 (33) & $23(21)$ & $19(18)$ & $9(8)$ & $41(38)$ & 30 (28) & $93(86)$ \\
\hline Female & 22 & $6(27)$ & $6(27)$ & $6(27)$ & $\mathbf{0}(\mathbf{0})$ & 7 (32) & $6(27)$ & $16(73)$ \\
\hline \multicolumn{9}{|c|}{ Disease extent } \\
\hline LD & 18 & $8(44)$ & $3(17)$ & $6(33)$ & 3 (17) & $8(44)$ & $4(22)$ & $16(89)$ \\
\hline ED & 112 & $34(30)$ & $26(23)$ & $19(17)$ & $6(5)$ & $40(36)$ & 32 (29) & $93(83)$ \\
\hline \multicolumn{9}{|l|}{ PS } \\
\hline $0-1$ & 95 & 33 (35) & $20(21)$ & $21(22)$ & $8(8)$ & $29(31)^{a}$ & $27(28)$ & $80(84)$ \\
\hline $2-4$ & 35 & $9(26)$ & $9(26)$ & $4(11)$ & $1(3)$ & $19(54)$ & $9(26)$ & $29(83)$ \\
\hline
\end{tabular}

ABC, ATP-binding cassette; Pgp, P-glycoprotein; MRP, multidrug resistance protein; BCRP, breast cancer resistance protein; ERCC, excision repair cross-complementation group;

BRCA, breast cancer susceptibility gene; LD, limited disease; ED, extensive disease; PS, performance status

a $=0.0223$ 
Table 5 Summarv of relationship between clinical variables and response to chemotherapv and survival

\begin{tabular}{|c|c|c|c|c|c|c|c|}
\hline & $\mathbf{n}$ & Response rate (\%) & $p$ & PFS (mo) & $p$ & MST (mo) & $p$ \\
\hline Total & 130 & 79 & & 5.2 & & 9.0 & \\
\hline \multicolumn{8}{|l|}{ Age } \\
\hline$<70$ & 83 & 80 & $>0.9999$ & 5.1 & 0.1296 & 9.4 & 0.3493 \\
\hline$\geq 70$ & 47 & 81 & & 5.4 & & 10.9 & \\
\hline \multicolumn{8}{|l|}{ Gender } \\
\hline Male & 108 & 81 & 0.7715 & 5.1 & 0.5496 & 9.4 & 0.6528 \\
\hline Female & 22 & 77 & & 5.7 & & 13.2 & \\
\hline \multicolumn{8}{|c|}{ Disease extent } \\
\hline LD & 18 & 67 & 0.2277 & 5.6 & 0.4838 & 9.4 & 0.8856 \\
\hline ED & 112 & 82 & & 5.2 & & 10.4 & \\
\hline \multicolumn{8}{|l|}{ PS } \\
\hline $0-1$ & 95 & 82 & 0.4584 & 5.5 & $0.0199 *$ & 10.8 & $0.0159 *$ \\
\hline $2-4$ & 35 & 74 & & 4.2 & & 8.1 & \\
\hline
\end{tabular}

LD, limited disease; ED, extensive disease; PS, performance status; PFS, progression-free survival; MST, median survival time 
Table 6 Association between expression of ABC transporter and DNA excision repair proteins and response to chemotherapy and survival $(\mathrm{n}=130)$

\begin{tabular}{|c|c|c|c|c|c|c|c|}
\hline & $n$ & Response rate (\%) & $p$ & PFS (mo) & $p$ & MST (mo) & $p$ \\
\hline \multicolumn{8}{|c|}{$\mathrm{C}_{\mathrm{s}}$} \\
\hline Positive & 42 & 83 & 0.6730 & 5.5 & 0.7257 & 10.5 & 0.3006 \\
\hline Negative & 88 & 78 & & 5.1 & & 9.9 & \\
\hline \multicolumn{8}{|l|}{ MRP1 } \\
\hline Positive & 29 & 90 & 0.1902 & 5.3 & 0.8141 & 11.0 & 0.2245 \\
\hline Negative & 101 & 77 & & 5.2 & & 9.4 & \\
\hline \multicolumn{8}{|l|}{ MRP2 } \\
\hline Positive & 25 & 64 & 0.0515 & 5.6 & 0.5832 & 12.6 & 0.1261 \\
\hline Negative & 105 & 84 & & 5.2 & & 9.3 & \\
\hline \multicolumn{8}{|l|}{ MRP3 } \\
\hline Positive & 9 & 78 & $>0.9999$ & 5.2 & 0.3181 & 11.9 & 0.1326 \\
\hline Negative & 121 & 80 & & 5.3 & & 9.4 & \\
\hline \multicolumn{8}{|l|}{ BCRP } \\
\hline Positive & 48 & 69 & $0.0260 *$ & 4.0 & 0.0103* & 9.1 & 0.1427 \\
\hline Negative & 82 & 87 & & 5.6 & & 10.6 & \\
\hline \multicolumn{8}{|l|}{ ERCC1 } \\
\hline Positive & 36 & 89 & 0.1452 & 5.4 & 0.5383 & 11.9 & 0.6251 \\
\hline Negative & 94 & 77 & & 4.3 & & 9.3 & \\
\hline \multicolumn{8}{|l|}{ BRCA1 } \\
\hline Positive & 109 & 79 & 0.5666 & 5.3 & 0.8404 & 10.5 & 0.4611 \\
\hline Negative & 21 & 86 & & 4.7 & & 8.1 & \\
\hline
\end{tabular}

ABC, ATP-binding cassette; Pgp, P-glycoprotein; MRP, multidrug resistance protein; BCRP, breast cancer resistance protein; ERCC, excision repair crosscomnlementation oroun. RRCA hreact cancer cuscentihilitv oene. PFS nroorescion-free survival MST median survival time 
Table 7 Multivariate analvsis for response $(n=130)$

\begin{tabular}{ccccc}
\multicolumn{5}{c}{ Table 7 Multivariate analvsis for response $(\mathrm{n}=130)$} \\
\hline Variables & Category & Risk ratio & $\mathbf{9 5 \%}$ CI & $p$ \\
\hline Age & $<70$ vs. $\geq 70$ & $\mathbf{0 . 7 0 1}$ & $\mathbf{0 . 2 6 3 - 1 . 8 6 9}$ & $\mathbf{0 . 4 7 7 6}$ \\
Gender & Female vs. Male & $\mathbf{0 . 8 5 7}$ & $\mathbf{0 . 2 5 8 - 2 . 8 4 8}$ & $\mathbf{0 . 8 0 1 4}$ \\
Disease extent & LD vs. ED & 1.81 & $\mathbf{0 . 5 4 5 - 6 . 0 1 8}$ & $\mathbf{0 . 3 3 2 9}$ \\
PS & $\mathbf{0 - 1}$ vs. $2-4$ & $\mathbf{1 . 3 1 5}$ & $\mathbf{0 . 4 7 1 - 3 . 6 7 6}$ & $\mathbf{0 . 6 0 1 3}$ \\
MRP2 & $(-)$ vs. $(+)$ & $\mathbf{2 . 2 3 8}$ & $\mathbf{0 . 7 7 9 - 6 . 4 2 9}$ & $\mathbf{0 . 1 3 4 6}$ \\
BCRP & $(-)$ vs. $(+)$ & $\mathbf{2 . 8 0 4}$ & $\mathbf{1 . 1 0 3 - 7 . 1 2 8}$ & $\mathbf{0 . 0 3 0 3}$ \\
\hline
\end{tabular}


Table 8 Multivariate analvsis for survival $(n=130)$

\begin{tabular}{|c|c|c|c|c|}
\hline \multicolumn{5}{|c|}{ A. progression-free survival } \\
\hline Variables & Category & Risk ratio & $95 \% \mathrm{CI}$ & $p$ \\
\hline Age & $<70$ vs. $\geq 70$ & 0.691 & $0.464-1.028$ & 0.0682 \\
\hline Gender & Female vs. Male & 1.062 & $0.650-1.733$ & 0.8105 \\
\hline Disease extent & LD vs. ED & 0.87 & $0.501-1.512$ & 0.6251 \\
\hline PS & $0-1$ vs. $2-4$ & 1.592 & $1.046-2.424$ & $0.0299 *$ \\
\hline BCRP & $(-)$ vs. $(+)$ & 1.614 & $1.102-2.363$ & 0.0138* \\
\hline \multicolumn{5}{|c|}{ B. overall survival } \\
\hline Variables & Category & Risk ratio & $95 \% \mathrm{CI}$ & $p$ \\
\hline Age & $<70$ vs. $\geq 70$ & 0.832 & $0.565-1.224$ & 0.3496 \\
\hline Gender & Female vs. Male & 1.067 & 0.658-1.729 & 0.7936 \\
\hline Disease extent & LD vs. ED & 1.131 & 0.673-1.901 & 0.6430 \\
\hline PS & 0-1 vs. $2-4$ & 1.588 & 1.047-2.407 & $0.0295 *$ \\
\hline BCRP & $(-)$ vs. $(+)$ & 1.235 & $0.831-1.833$ & 0.2962 \\
\hline
\end{tabular}

LD. limited disease: ED, extensive disease: PS, performance status: BCRP, breast cancer resistance protein 

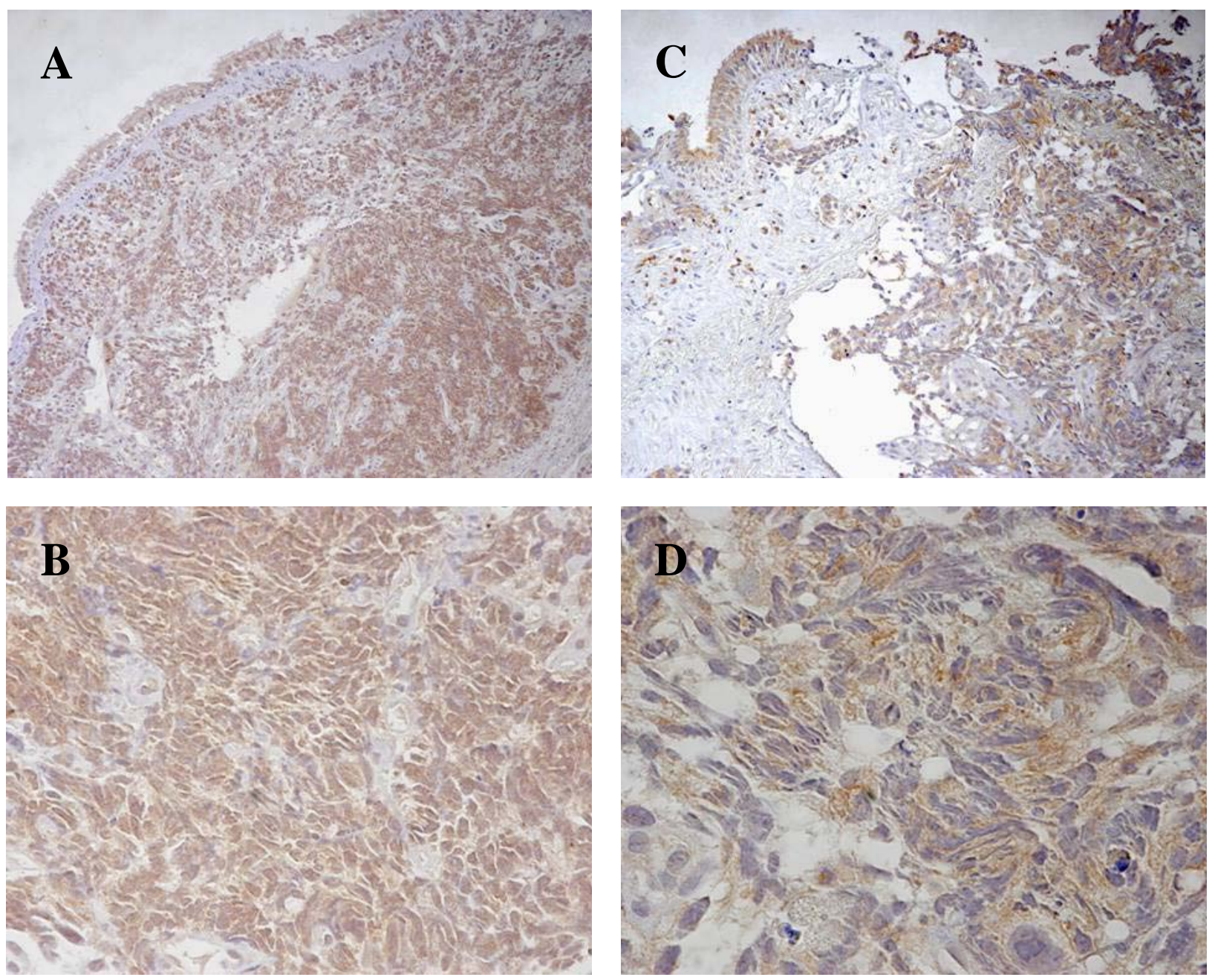

Fig. 1 
